\title{
Hypothesis
}

\section{Catalytic Peroxidation of Nitrogen Monoxide and Peroxynitrite by Globins}

\author{
Elisabetta De Marinis ${ }^{1}$, Luigi Casella ${ }^{2}$, Chiara Ciaccio ${ }^{3}$, Massimo Coletta ${ }^{3}$, \\ Paolo Visca $^{1,4}$ and Paolo Ascenzi ${ }^{1,4}$ \\ ${ }^{1}$ Dipartimento di Biologia e Laboratorio Interdipartimentale di Microscopia Elettronica, Università Roma Tre, Roma, Italy \\ ${ }^{2}$ Dipartimento di Chimica Generale, Università di Pavia, Pavia, Italy \\ ${ }^{3}$ Dipartimento di Medicina Sperimentale e Scienze Biochimiche, Università di Roma 'Tor Vergata', Roma, Italy \\ ${ }^{4}$ Istituto Nazionale per le Malattie Infettive I.R.C.C.S. 'Lazzaro Spallanzani', Roma, Italy
}

\begin{abstract}
Summary
Globins are generally considered as carriers of diatomic gaseous ligands (e.g., $\mathrm{O}_{2}$ and $\mathrm{NO}$ ) in metazoa. Recently, the (pseudo-)enzymatic activity of globins towards reactive nitrogen and oxygen species has been elucidated. In particular, some globins (e.g., hemoglobin and myoglobin) catalyze the enzymatic scavenging of $\mathrm{NO}$ and peroxynitrite in the presence of $\mathrm{H}_{2} \mathrm{O}_{2}$. Indeed, $\mathrm{H}_{2} \mathrm{O}_{2}$ oxidizes some globins leading to the formation of water and of the heme-protein ferryl derivative, which, in turn, oxidizes NO and peroxynitrite leading to the formation of the globin ferric species, $\mathrm{NO}_{2}^{-}$, and $\mathrm{NO}_{3}^{-}$. Here, we hypothesize that NO, peroxynitrite, and $\mathrm{H}_{2} \mathrm{O}_{2}$ are co-substrates for the peroxidase activity of some globins, this catalytic activity was reported in $\mathbf{1 9 0 0}$ for the first time, even though the substrates have never been identified firmly up to now. ( 2008 IUBMB
\end{abstract}

IUвмв Life, 61(1): 62-73, 2009

Keywords globins; catalytic peroxidation; nitrogen monoxide; peroxynitrite; hydrogen peroxide; oxidative stress; nitrosative stress.

Abbreviations EPO, eosinophil peroxidase; heme-Fe(III), ferric heme-protein; heme- $\mathrm{Fe}(\mathrm{IV})=\mathrm{O}$, ferryl heme-protein; heme-Fe(III)-ONO, $O$-nitrito ferric heme-protein; $\mathrm{Hb}$, hemoglobin; Lb, leghemoglobin; $\mathrm{Mb}$, myoglobin; MPO, myeloperoxidase; Ngb, neuroglobin; trHbN, truncated $\mathrm{Hb} \mathrm{N}$; trHbO, truncated $\mathrm{Hb} \mathrm{O}$.

The hemoglobin $(\mathrm{Hb})$ superfamily includes several hemeproteins, generally referred to as globins, which are found in all

Received 22 July 2008; accepted 23 September 2008

Address correspondence to: Paolo Ascenzi, Department of Biology and Interdepartmental Laboratory for Electron Microscopy, University Roma Tre, Viale Guglielmo Marconi 446, I-00146 Roma, Italy. Tel: +3906 5733 3200(2). Fax: +3906 5733 6321. E-mail: ascenzi@ uniroma3.it kingdoms of living organisms $(1,2)$. Globin functions have been the subject of active debate, in addition to dioxygen transport and storage. Several functions have been proposed recently, including control of nitrogen monoxide levels, $\mathrm{O}_{2}$ sensing, and dehaloperoxidase activity (3-15).

Globins share physical, spectroscopic, and chemical similarities with peroxidases $(16,17)$. In fact, as demonstrated first in 1900 (18), Hb reacts readily with hydrogen peroxide $\left(\mathrm{H}_{2} \mathrm{O}_{2}\right)$. In 1923, the peroxidase activity of $\mathrm{Hb}$ has been reported (19), and in 1938, the modulation of the peroxidase activity of $\mathrm{Hb}$ by haptoglobin has been demonstrated (20). The reaction of myoglobin $(\mathrm{Mb})$ with $\mathrm{H}_{2} \mathrm{O}_{2}$, on the other hand, apparently was not considered until 1952 (21), and the ability of $\mathrm{Mb}$ to catalyze peroxide oxidation of substrates was not reported until 1955 (22). Upon reaction with $\mathrm{H}_{2} \mathrm{O}_{2}, \mathrm{Mb}$ and $\mathrm{Hb}$ form the cytotoxic ferryl derivative (heme- $\mathrm{Fe}(\mathrm{IV})=\mathrm{O}$ ), which is similar to compound II formed by peroxidases $(23,24)$. Heme-Fe(IV) $=\mathrm{O}$ is able to oxidize a wide range of reducing substrates, such as phenols and aromatic amines, even though substrate peroxidation by $\mathrm{Hb}$ and $\mathrm{Mb}$ is far less efficient than that of peroxidases $(24,25)$, ruling out the possibility that the potential peroxidase activity of $\mathrm{Hb}$ and $\mathrm{Mb}$ is exerted on this class of substrates under normal conditions.

Here, we hypothesize that the capability of some globins (e.g., $\mathrm{Hb}$ and $\mathrm{Mb}$ ) to form a compound II-like species under oxidative stress may be actually exploited to avoid the building up of NO and peroxynitrite, ${ }^{1}$ which can be then identified as the 'true' substrates for the peroxidase activity of $\mathrm{Hb}$ and $\mathrm{Mb}$.

Heme-proteins share the ability of detoxifying nitrogen reactive species, for example, NO. Even though leukocyte peroxi-

\footnotetext{
${ }^{1}$ The term peroxynitrite is used in the text to refer generically to both $\mathrm{ONOO}^{-}$and its conjugated acid HOONO (38).
} 
Table 1

NO scavenging by heme-Fe(II)- $\mathrm{O}_{2}$

\section{Reductase}

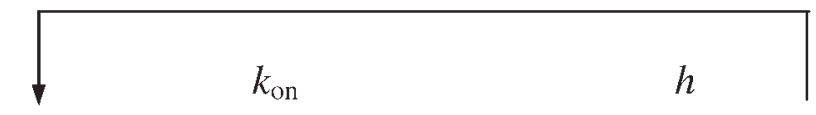

$$
\text { heme-Fe(II)- } \mathrm{O}_{2}+\mathrm{NO} \rightarrow \text { heme-Fe(III)-OONO } \rightarrow \text { heme-Fe(III) }+\mathrm{NO}_{3}^{-}
$$

\begin{tabular}{|c|c|c|}
\hline Heme-protein & $k_{\mathrm{on}}\left(\mathrm{M}^{-1} \mathrm{~s}^{-1}\right)$ & $h\left(\mathrm{~s}^{-1}\right)$ \\
\hline 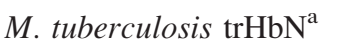 & $7.5 \times 10^{8}$ & Fast \\
\hline M. tuberculosis trHbO ${ }^{\mathrm{b}}$ & $6.0 \times 10^{5}$ & Fast \\
\hline M. leprae $\mathrm{trHbO}^{\mathrm{c}}$ & $2.1 \times 10^{6}$ & 3.4 \\
\hline E. coli flavoHb ${ }^{\mathrm{d}}$ & $\geq 6.0 \times 10^{8}$ & $\sim 2.0 \times 10^{2}$ \\
\hline Glycine $\max \mathrm{Lb}^{\mathrm{e}}$ & $8.2 \times 10^{7}$ & Fast \\
\hline Horse heart $\mathrm{Mb}^{\mathrm{f}}$ & $4.4 \times 10^{7}$ & $>3.4 \times 10^{2}$ \\
\hline Murine $\mathrm{Ngb}^{\mathrm{g}}$ & $>7.0 \times 10^{7}$ & $\sim 3.0 \times 10^{2}$ \\
\hline Human $\mathrm{Hb}$ & $8.9 \times 10^{7 \mathrm{f}}$ & $\begin{array}{l}>5.8 \times 10^{1 \mathrm{~h}} \\
>3.3 \times 10^{1 \mathrm{~h}}\end{array}$ \\
\hline
\end{tabular}

${ }^{\mathrm{a}} \mathrm{pH}=7.5$ and $23.0^{\circ} \mathrm{C}$. From $(87)$.

${ }^{\mathrm{b}} \mathrm{pH}=7.5$ and $23.0^{\circ} \mathrm{C}$. From $(88)$.

${ }^{\mathrm{c}} \mathrm{pH}=7.3$ and $20.0^{\circ} \mathrm{C}$. From $(82)$.

${ }_{\mathrm{pH}}=7.0$ and $20.0^{\circ} \mathrm{C}$. From (36).

${ }^{\mathrm{e}} \mathrm{pH}=7.3$ and $20.0^{\circ} \mathrm{C}$. From (89).

${ }_{\mathrm{p}}^{\mathrm{f} H}=7.0$ and $20.0^{\circ} \mathrm{C}$. From $(90)$.

${ }_{\mathrm{g}}^{\mathrm{pH}}=7.0$ and $20.0^{\circ} \mathrm{C}$. From $(91)$.

${ }^{\mathrm{h}}$ The two values represent the decay rates for $\mathrm{Fe}(\mathrm{III}) \mathrm{OONO} \alpha-$ and $\beta$ - $\mathrm{Hb}$ subunits. $\mathrm{pH}=7.5$ and $20.0^{\circ} \mathrm{C}$. From (27).

dases are believed to play a dominant role in the consumption of NO-derived oxidants at sites of inflammation (as a part of host defenses against oxidative tissue injury), ferrous oxygenated $\mathrm{Hb}$ and $\mathrm{Mb}\left(\mathrm{HbO}_{2}\right.$ and $\mathrm{MbO}_{2}$, respectively) indeed are involved in the major pathway for NO removal from the vascular compartment and in the protection of mitochondrial respiration $(4,6,10,12,14,26)$, respectively. Hereafter, we deal with these reactions under aerobic and anaerobic conditions, discriminating between reducing environmental conditions and oxidative conditions.

Under aerobic and reducing conditions, the rapid and irreversible reaction of the ferrous oxygenated derivative of hemeproteins (heme-Fe(II)- $\mathrm{O}_{2}$ ) with $\mathrm{NO}$ and peroxynitrite occurs. This reaction gives rise to the ferric species (heme-Fe(III)) and nitrate $\left(\mathrm{NO}_{3}^{-}\right)$as the final reaction products, displaying as a reaction intermediate the heme-Fe(III)-peroxynitrite complex $(27,28)$ (see Table 1). On the other hand, the reaction of heme$\mathrm{Fe}(\mathrm{II})-\mathrm{O}_{2}$ with peroxynitrite gives rise to heme- $\mathrm{Fe}(\mathrm{IV})=\mathrm{O}$, nitrite $\left(\mathrm{NO}_{2}^{-}\right), \mathrm{O}_{2}$, and $\mathrm{H}^{+}$; then, heme-Fe(IV) $=\mathrm{O}$ may react with a second peroxynitrite molecule, leading to the formation of the heme-Fe(III) species and the peroxynitrite radical (ONOO`) as the final reaction products (28) (see Table 2).

NO scavenging is also facilitated by the direct interaction of ferrous nitrosylated heme-Fe(II) (heme-Fe(II)-NO) with $\mathrm{O}_{2}$, giv- ing rise to heme-Fe(III) and $\mathrm{NO}_{3}^{-}$as the final reaction products. However, the intermediate(s) are different for reaction(s) catalyzed by the hexa-coordinated human neuroglobin $(\mathrm{Ngb})$ on one side and by penta-coordinated globins, such as Mb (29-31) (see Table 3). $\mathrm{O}_{2}$-mediated $\mathrm{NO}$ scavenging by ferrous nitrosylated horse heart $\mathrm{Mb}$ and human $\mathrm{Hb}$ ( $\mathrm{Mb}$ (II)-NO and $\mathrm{Hb}$ (II)-NO, respectively) appears to occur with a reaction mechanism, in which NO that is initially bound to heme-Fe(II) is displaced by $\mathrm{O}_{2}$ but may stay trapped in a protein cavity(ies) close to the heme. In the second step, ferrous oxygenated horse heart $\mathrm{Mb}$ and human $\mathrm{Hb}\left(\mathrm{Mb}(\mathrm{II})-\mathrm{O}_{2}\right.$ and $\mathrm{Hb}(\mathrm{II})-\mathrm{O}_{2}$, respectively) react with NO giving the transient heme-Fe(III)-peroxynitrite species preceding the formation of the final products. The rate-limiting step in catalysis appears to be NO dissociation from heme$\mathrm{Fe}(\mathrm{II})-\mathrm{NO}$ (29). A slight rearrangement within the protein structure, taking place after formation of ferric human $\mathrm{Ngb}$ $[\mathrm{Ngb}(\mathrm{III})]$ and possibly reflecting the penta-to-hexa-coordination transition of the heme-Fe-atom, has been postulated to be the rate- limiting step in $\mathrm{O}_{2}$-mediated $\mathrm{NO}$ scavenging (30).

$\mathrm{NO}$ and peroxynitrite detoxification by heme-Fe(II)- $\mathrm{O}_{2}$ and $\mathrm{O}_{2}$-mediated $\mathrm{NO}$ scavenging by heme-Fe(II)-NO, indeed, all reflect the superoxide character of the initial or transient heme$\mathrm{Fe}(\mathrm{II})-\mathrm{O}_{2}$ species (i.e., heme-Fe(III)- $\mathrm{O}_{2}^{-}$) (32) (see Tables 1, 2, and 3$)$. 
Table 2

Peroxynitrite scavenging by heme-Fe(II)- $\mathrm{O}_{2}$ and heme-Fe(IV) $=\mathrm{O}$

\section{Reductase}

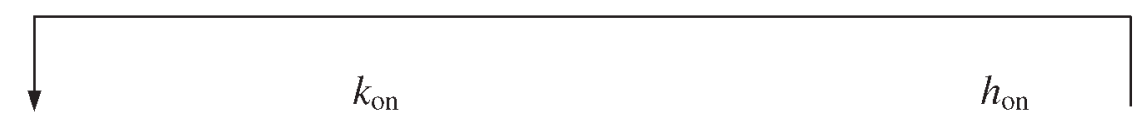

$$
\begin{aligned}
& \text { heme-Fe }(\mathrm{II})-\mathrm{O}_{2}+\mathrm{HOONO} \rightarrow \text { heme-Fe}(\mathrm{IV})=\mathrm{O}+\mathrm{HOONO}+\mathrm{H}^{+} \rightarrow \text { heme-Fe}(\mathrm{III})+\mathrm{ONOO}^{\bullet} \\
&+\mathrm{NO}_{2}^{-} \\
&+\mathrm{O}_{2} \\
&+\mathrm{H}^{+} \\
& \mathrm{H}_{2} \mathrm{O}_{2}
\end{aligned}
$$

\begin{tabular}{lcc}
\hline Heme-protein & $k_{\text {on }}\left(\mathrm{M}^{-1} \mathrm{~s}^{-1}\right)$ & $h_{\text {on }}\left(\mathrm{M}^{-1} \mathrm{~s}^{-1}\right)$ \\
\hline M. leprae trHbO & $1.3 \times 10^{4}$ \\
Glycine max $\mathrm{Lb}^{\mathrm{b}}$ & $4.8 \times 10^{4}$ & $2.1 \times 10^{4}$ \\
Horse heart $\mathrm{Mb}^{\mathrm{c}}$ & $5.5 \times 10^{4}$ & $2.2 \times 10^{4}$ \\
Human $\mathrm{Hb}^{\mathrm{d}}$ & $5.4 \times 10^{4}$ & $3.3 \times 10^{4}$ \\
\hline
\end{tabular}

${ }^{\mathrm{a}} \mathrm{pH} 7.3$ and $20.0^{\circ} \mathrm{C}$. From (83).

${ }^{\mathrm{b}} \mathrm{pH} 7.3$ and $20.0^{\circ} \mathrm{C}$. From (89).

${ }^{\mathrm{c}} \mathrm{pH} 7.5$ and $20.0^{\circ} \mathrm{C}$. From (92).

${ }^{\mathrm{d}} \mathrm{pH} 7.4$ and $20.0^{\circ} \mathrm{C}$. From (93).

Heme-Fe(II)-NO also facilitates peroxynitrite scavenging; this reaction proceeds in two steps, a rapid conversion from heme-Fe(II)-NO to the heme-Fe(III)-NO intermediate, which then dissociates into NO and heme-Fe(III) (28) (see Table 4). Preliminary results $(33,34)$ indicate that deoxygenated and ferrous carbonylated globins may also facilitate peroxynitrite detoxification, giving rise to the heme-Fe(III) species.

All reactions depicted in Tables $1-4$ are considered as 'pseudo-enzymatic processes' because they need a reductase partner(s) to restore heme-Fe(II), which is absolutely necessary for a new catalytic cycle. In particular, NADH-metHb and metMb reductases catalyze the conversion of heme-Fe(III) to heme-Fe(II) in vivo. As a matter of fact, the enzymatic heme$\mathrm{Fe}(\mathrm{III})$ reduction is the rate-limiting step of the whole process, this representing a severe limitation for the efficiency of these mechanisms in vivo $(4,28,35-43)$.

Under highly oxidative conditions, the redox equilibrium of globins is shifted in favor of the heme-Fe(III) form, impairing their role as $\mathrm{O}_{2}$ carriers. However, under these conditions, usually the high $\mathrm{H}_{2} \mathrm{O}_{2}$ concentration facilitates the oxidation of the heme-Fe(III) of some globins (e.g., $\mathrm{Hb}$ and $\mathrm{Mb}$ ), giving rise to the formation of the compound II-like species heme-Fe(IV) $=\mathrm{O}$. This highly oxidative form facilitates $\mathrm{NO}$, peroxynitrite and $\mathrm{NO}_{2}^{-}$scavenging (see Tables 2, 5, and 6), because NO detoxification by heme- $\mathrm{Fe}(\mathrm{IV})=\mathrm{O}$ leads to the formation of heme$\mathrm{Fe}(\mathrm{III})$ and $\mathrm{NO}_{2}^{-}$(44-47) (see Table 5). The reactions of heme-
$\mathrm{Fe}(\mathrm{IV})=\mathrm{O}$ with peroxynitrite and $\mathrm{NO}_{2}^{-}$generate $\mathrm{ONOO}^{\bullet}$ and the nitrogen dioxide radical $\left({ }^{\bullet} \mathrm{NO}_{2}\right)$, respectively, which could contribute to tyrosine nitration and thus to the inactivation of proteins $(28,48-51)$ (see Tables 2 and 6). The reaction of heme-Fe(IV) $=\mathrm{O}$ with $\mathrm{NO}$ (see Table 5) is significantly faster than those of heme-Fe(IV) $=\mathrm{O}$ with peroxynitrite and $\mathrm{NO}_{2}^{-}$(see Tables 2 and 6). These reactions, depicted in Tables 2, 5, and 6 , do not require partner oxido-reductive enzyme(s), because the system oscillates between the oxidation of the heme-Fe(III) species to heme-Fe(IV) $=\mathrm{O}$ by $\mathrm{H}_{2} \mathrm{O}_{2}$, and the heme-Fe(IV) $=\mathrm{O}$ reduction back to heme-Fe(III) by $\mathrm{NO}$, peroxynitrite, and $\mathrm{NO}_{2}^{-}$ (28, 44-47). Interestingly, catalytic parameters for NO scavenging by heme-Fe(II)- $\mathrm{O}_{2}$ (43) and heme-Fe(IV) $=\mathrm{O}$ (47) are closely similar (see Tables 1 and 5) and high enough to indicate that both reactions could occur efficiently in vivo.

In contrast with penta-coordinated globins (e.g., $\mathrm{Hb}$ and $\mathrm{Mb}$ ) (28, 44-51), heme-Fe(III) human Ngb apparently does not generate the heme-Fe(IV) $=\mathrm{O}$ form when exposed to $\mathrm{H}_{2} \mathrm{O}_{2}$ and peroxynitrite, another feature of $\mathrm{Ngb}$ that may contribute to neuronal survival after hypoxia and that may be related to heme-Fe-atom hexa-coordination $(28,30,31)$.

Beside globins, heme-Fe(IV) $=\mathrm{O}$ peroxidases may facilitate $\mathrm{NO}$ and $\mathrm{NO}_{2}^{-}$detoxification (see Tables 5, 6, and 7). However, in the case of mammalian peroxidases, such as myeloperoxidase (MPO) and eosinophil peroxidase (EPO), the rate constants for NO oxidation to $\mathrm{NO}_{2}^{-}$are 2-3 orders of magnitude lower than 
Table 3

$\mathrm{O}_{2}$-mediated $\mathrm{NO}$ scavenging by heme-Fe(II)-NO

\author{
Human $\mathrm{Ngb}^{\mathrm{a}}$ \\ Reductase

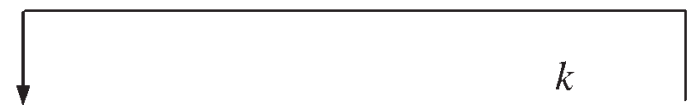 \\ heme-Fe(II)-NO $+\mathrm{O}_{2} \rightarrow$ heme-Fe(III)* $\rightarrow$ heme-Fe(III) \\ $+\mathrm{NO}_{3}^{-}$ \\ $k=5.0 \times 10^{-4} \mathrm{~s}^{-1}$
}

Horse heart $\mathrm{Mb}^{\mathrm{b}}$

\title{
Reductase
}

$\begin{array}{|ll|}\text { slow } & \text { fast }\end{array}$

heme-Fe(II)-NO $+\mathrm{O}_{2} \leftrightarrow$ heme-Fe(II)-O $\mathrm{O}_{2}+\mathrm{NO} \rightarrow$ heme-Fe(III)-OONO $\rightarrow$ heme-Fe(III) $+\mathrm{NO}_{3}^{-}$

$k=2.6 \times 10^{-4} \mathrm{~s}^{-1}$

\section{Human $\mathrm{Hb}^{\mathrm{c}}$}

\section{Reductase}

$\downarrow$ slow fast

\section{heme-Fe(II)-NO $+\mathrm{O}_{2} \leftrightarrow$ heme-Fe(II)- $\mathrm{O}_{2}+\mathrm{NO} \rightarrow$ heme-Fe(III) $+\mathrm{NO}_{3}^{-}$}

${ }^{\mathrm{a}} \mathrm{pH} 7.5$ and $25.0^{\circ} \mathrm{C}$. From (30).

${ }^{\mathrm{b}} \mathrm{pH} 7.0$ and $20.0^{\circ} \mathrm{C}$. From (94).

${ }^{\mathrm{c}} \mathrm{pH} 7.2$ and room temperature. From (95).

those reported for the heme-Fe (IV) $=\mathrm{O}$ derivative of globins, whereas in the case of plant peroxidases, such as horseradish peroxidase (HRP), the rate constant is only 10-fold slower than for globins $(47,48,52-59)$ (see Table 5). Further, the formation of the heme-Fe(III)-ONO species is significantly faster in globins than in peroxidases (and possibly in catalase), where the formation of the heme-Fe(III)-ONO species is the rate-limiting step. Conversely, the dissociation of the heme-Fe(III)-ONO species and the $O$-nitrito isomerization is significantly faster in peroxidases than in the heme-Fe(III) species of globins where it represents instead the rate-limiting step (44-47, 52-55) (see Table 5). On the other hand, the rate constant for $\mathrm{NO}_{2}^{-}$ scavenging by heme-Fe(IV) $=\mathrm{O}$ MPO is similar to that observed for heme-Fe(IV) $=\mathrm{O}$ globin action $(44-47,53)$ (see Table 6). 
Table 4

Peroxynitrite scavenging by heme-Fe(II)-NO

\section{Reductase}

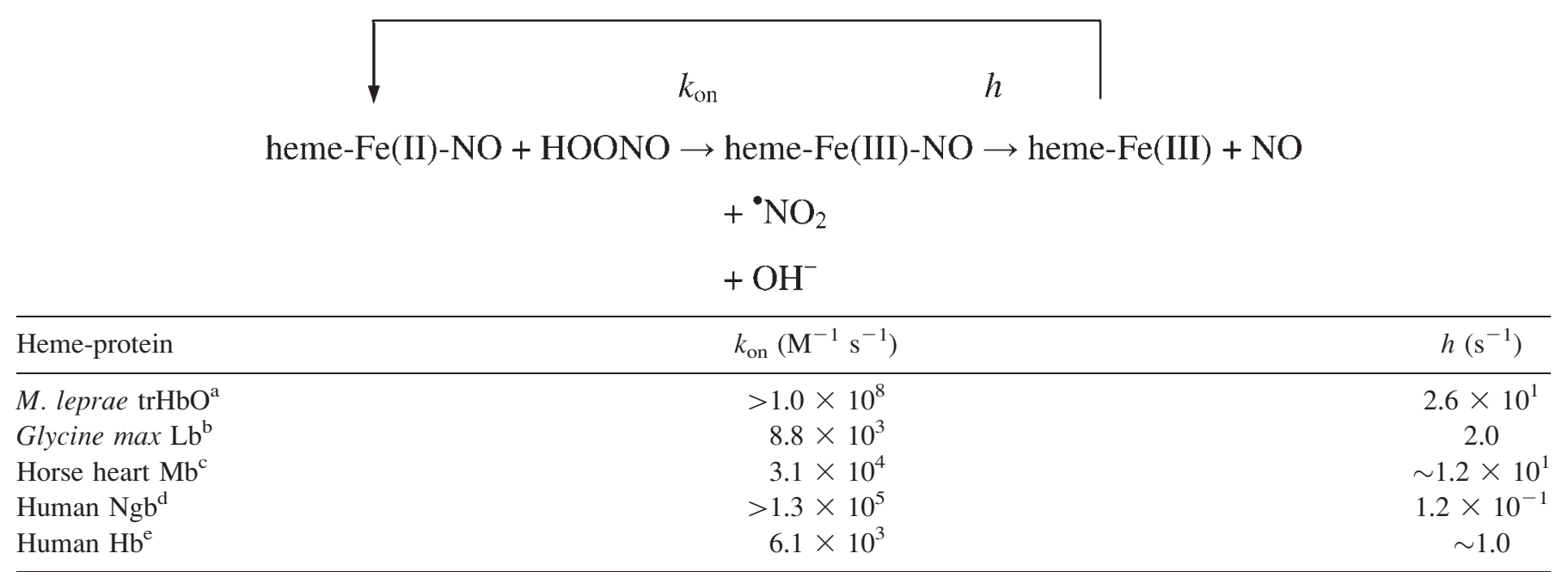

${ }^{\mathrm{a}} \mathrm{pH} 7.3$ and $20.0^{\circ} \mathrm{C}$. From (83).

${ }^{\mathrm{b}} \mathrm{pH} 7.3$ and $20.0^{\circ} \mathrm{C}$. From (46).

${ }^{\mathrm{c}} \mathrm{pH} 7.5$ and $20.0^{\circ} \mathrm{C}$. From (96).

${ }^{\mathrm{d}} \mathrm{pH} 7.2$ and $25.0^{\circ} \mathrm{C}$. From (30).

${ }^{\mathrm{e}} \mathrm{pH} 7.2$ and $20.0^{\circ} \mathrm{C}$. From (97).

Table 5

NO scavenging by heme- $\mathrm{Fe}(\mathrm{IV})=\mathrm{O}$

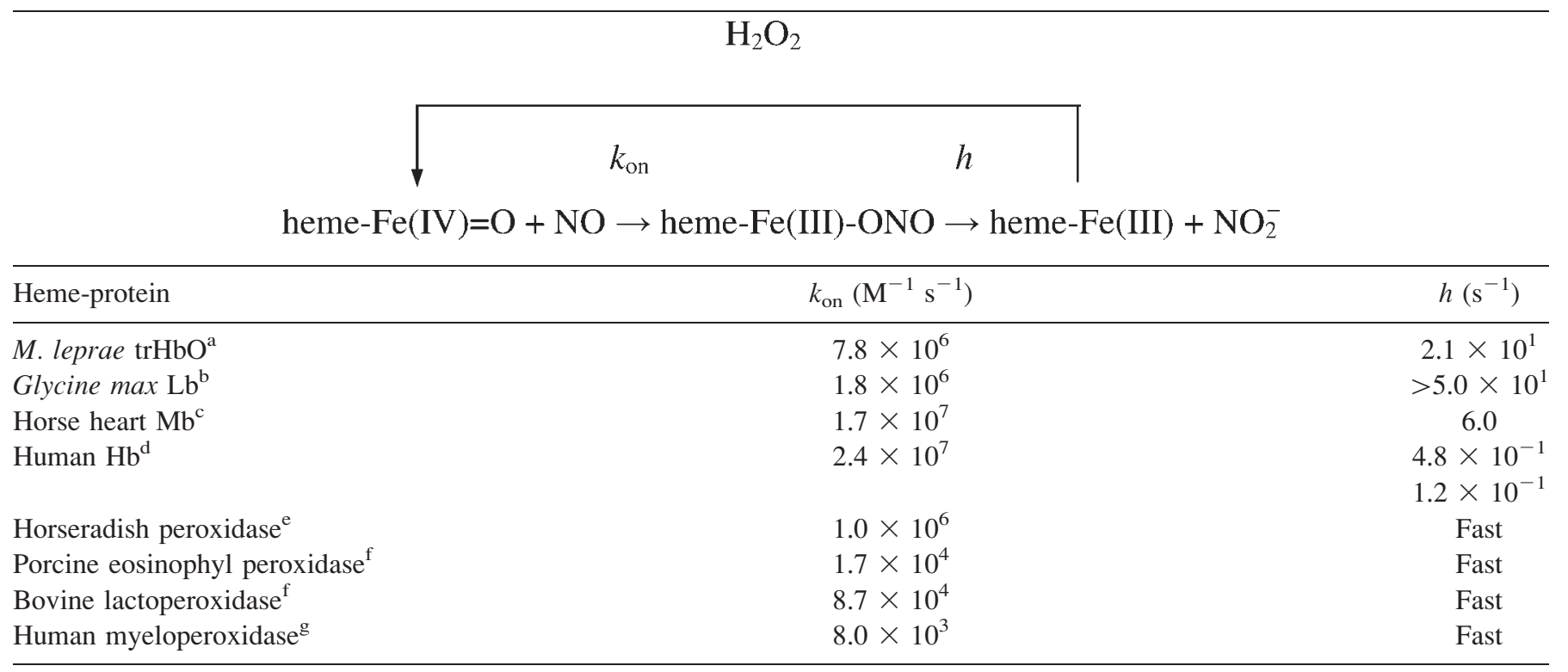

${ }^{\mathrm{a}} \mathrm{pH}=7.2$ and $20.0^{\circ} \mathrm{C}$. From (47)

${ }^{\mathrm{b}} \mathrm{pH}=7.0$ and $20.0^{\circ} \mathrm{C}$. From (46).

${ }^{\mathrm{c}} \mathrm{pH}=7.0$ and $20.0^{\circ} \mathrm{C}$. From (44).

${ }_{\mathrm{d}}^{\mathrm{d} H}=7.0$ and $20.0^{\circ} \mathrm{C}$. Biphasic kinetics of heme-Fe(III)-ONO decay (represented by values of $h$ ) has been attributed to $\alpha$ - and $\beta$-chains. From (45).

${ }^{\mathrm{e}} \mathrm{pH}=7.4$ and $20.0^{\circ} \mathrm{C}$. From (52).

${ }^{\mathrm{f}} \mathrm{pH}=7.0$ and $25.0^{\circ} \mathrm{C}$. From (54).

${ }^{\mathrm{g}} \mathrm{pH}=7.0$ and $25.0^{\circ} \mathrm{C}$. From (53). 
Table 6

$\mathrm{NO}_{2}^{-}$scavenging by heme-Fe $(\mathrm{IV})=\mathrm{O}$

$$
\mathrm{H}_{2} \mathrm{O}_{2}
$$

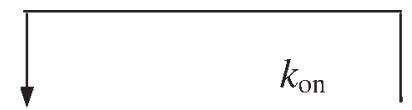

$$
\text { heme-Fe(IV) }=\mathrm{O}+\mathrm{NO}_{2}^{-} \rightarrow \text { heme-Fe(III) }+{ }^{\bullet} \mathrm{NO}_{2}
$$

\begin{tabular}{|c|c|}
\hline Heme-protein & $k_{\mathrm{on}}\left(\mathrm{M}^{-1} \mathrm{~s}^{-1}\right)$ \\
\hline M. leprae $\mathrm{trHbO}^{\mathrm{a}}$ & $3.1 \times 10^{3}$ \\
\hline Glycine $\max \mathrm{Lb}^{\mathrm{b}}$ & $2.1 \times 10^{2}$ \\
\hline Horse heart $\mathrm{Mb}^{\mathrm{c}}$ & $1.6 \times 10^{1}$ \\
\hline Human $\mathrm{Hb}^{\mathrm{d}}$ & $7.5 \times 10^{2}$ \\
\hline Human myeloperoxidase ${ }^{\mathrm{e}}$ & $5.5 \times 10^{2}$ \\
\hline
\end{tabular}

${ }^{\mathrm{a}} \mathrm{pH}=7.2$ and $20.0^{\circ} \mathrm{C}$. From (47).

${ }^{\mathrm{b}} \mathrm{pH}=7.0$ and $20.0^{\circ} \mathrm{C}$. From (46).

${ }^{\mathrm{c}} \mathrm{pH}=7.5$ and $20.0^{\circ} \mathrm{C}$. From (44).

${ }_{\mathrm{pH}}^{\mathrm{d}}=7.0$ and $20.0^{\circ} \mathrm{C}$. From (45).

${ }^{\mathrm{e}} \mathrm{pH}=7.0$ and $15.0^{\circ} \mathrm{C}$. From (53).

Both peroxidases and globins are able to perform the peroxynitrite detoxification under oxidative stress conditions. In the case of peroxidases, the reaction with peroxynitrite brings about the fast formation of the compound II-like heme-Fe(IV) $=\mathrm{O}$ species (60), likely through the formation of a transient Fe(III)peroxynitrite complex, followed by its conversion to heme$\mathrm{Fe}(\mathrm{IV})=\mathrm{O}$ and ${ }^{\bullet} \mathrm{NO}_{2}(61)$. This fast event is then followed by a very slow reduction of heme-Fe(IV) $=\mathrm{O}$ back to $\mathrm{Fe}(\mathrm{III})$, which is driven by the oxidation of $\mathrm{NO}_{2}^{-}$(in a redox equilibrium with - $\mathrm{NO}_{2}$ ) to $\mathrm{NO}_{3}^{-}$(61) (see Table 7). Although no kinetic parameters are instead available for these reactions in catalase, a role played by catalase in the detoxification of $\mathrm{NO}$ has been reported (55).

In the case of globins, horse heart heme-Fe(III) $\mathrm{Mb}$ and human heme-Fe(III) $\mathrm{Hb}$ catalyze the isomerization of peroxynitrite to $\mathrm{NO}_{3}^{-}(27,62)$ (see Tables 1, 3, 5, and 7); in contrast, peroxynitrite does not react with hexa-coordinated heme-Fe(III) human $\mathrm{Ngb}$, as reported for $\mathrm{H}_{2} \mathrm{O}_{2}(28,30,31)$.

Heme-Fe(III) species also facilitate NO scavenging through the formation of the $\mathrm{Fe}(\mathrm{III})-\mathrm{NO}$ complex, giving rise to heme$\mathrm{Fe}(\mathrm{II})-\mathrm{NO}$ as the final reaction product. This reaction proceeds in three steps: (i) reversible heme-Fe(III) nitrosylation (i.e., heme-Fe(III)-NO formation) followed by fast conversion to heme-Fe(II)-NO ${ }^{+}$; (ii) $\mathrm{H}_{2} \mathrm{O} / \mathrm{OH}^{-}$catalyzed conversion of heme$\mathrm{Fe}(\mathrm{II})-\mathrm{NO}^{+}$to heme-Fe(II); and (iii) reversible heme-Fe(II) nitrosylation by a second $\mathrm{NO}$ molecule (i.e., heme-Fe(II)-NO formation). NO binding to heme-Fe(III) $S$. inaequivalvis $\mathrm{HbI}$ and human $\mathrm{Ngb}(\mathrm{III})(30,63)$ appears to be rate limiting, whereas the conversion of heme-Fe(II)- $\mathrm{NO}^{+}$to heme-Fe(II) is the rate-limiting step for the reductive nitrosylation of hemeFe(III) Glycine max leghemoglobin (Lb(III)), sperm whale
$\mathrm{Mb}(\mathrm{III})$, human $\mathrm{Hb}(\mathrm{III})$, and human myeloperoxidase (46, 53, 64) (see Table 8).

Lastly, heme-based reactions involving peroxynitrite appear to be facilitated by carbon dioxide $\left(\mathrm{CO}_{2}\right)$. Indeed, peroxynitrite may rapidly react with $\mathrm{CO}_{2}$ forming an adduct, believed to be 1-carboxylato-2-nitrosodioxidane $\left(\mathrm{ONOOC}(\mathrm{O}) \mathrm{O}^{-}\right)$. This transient intermediate decays by homolysis of the $\mathrm{O}-\mathrm{O}$ bond giving rise to $\mathrm{NO}_{3}^{-}$and $\mathrm{CO}_{2}$ as final products, trioxocarbonate $\left({ }^{\bullet} 1^{-}\right)\left(\mathrm{CO}_{3}^{-}\right)$and ${ }^{\bullet} \mathrm{NO}_{2}$ being the reaction intermediates. Note that $\mathrm{CO}_{3}^{-}$and ${ }^{-} \mathrm{NO}_{2}$ are stronger oxidant species than peroxynitrite $(50,65)$.

The comparison of globin and peroxidase action (see Tables 5, 6, 7, and 8) allows the following considerations. (i) The detoxification activity of NO and peroxynitrite by the heme$\mathrm{Fe}(\mathrm{IV})=\mathrm{O}$ species of globins (occurring under oxidative conditions) is higher than that of peroxidases. (ii) The $\mathrm{NO}_{2}^{-}$detoxification activity of mammalian peroxidases is higher than that reported for plant peroxidases and globins. (iii) The heme$\mathrm{Fe}$ (III) derivative of peroxidases detoxifies peroxynitrite more efficiently than the heme- $\mathrm{Fe}(\mathrm{IV})=\mathrm{O}$ species of globins.

Peroxidation of classical peroxidase substrates (e.g., phenols) by globins occurs at a much slower rate, with respect to the heme-enzymes $(24,48,58)$. The different catalytic behavior of globins and peroxidases for different substrates might be due to the strong hydrogen bond present in peroxidases between the proximal histidyl residue and a conserved aspartate residue (45). Moreover, it may be also referred to the highly positive charge present in the heme distal side of peroxidases (see Fig. 1), which significantly lowers the $\mathrm{p} K_{\mathrm{a}}$ values of catalytic His and Arg distal residues $(66,67)$. This idea is further strengthened by the following: $(i)$ the evidence that site-directed mutants of horse heart Mb (Thr39Ile, Lys45Asp, Phe46Leu, and Ile107Phe) and sperm whale Mb (Thr67Arg and Thr67Arg/ Ser92Asp) display a significant increase of the peroxidase activity $(25,68,69)$, and (ii) site-directed mutants of cytochrome $c$ peroxidase (His175Gln, His175Glu, and His175Cys) and horseradish peroxidase (Arg38Leu, His42Glu, His42Gln) show a substantial decrease of the peroxidase activity (70-72).

The peroxidase activity of globins appears to be at the root of the Mycobacterium leprae ability to persist in vivo in the presence of reactive nitrogen and oxygen species. Indeed, during infection, $M$. leprae is faced with the host macrophagic environment, where low $\mathrm{pH}$, low $\mathrm{pO}_{2}$, high $\mathrm{pCO}_{2}$, combined with the toxic activity of reactive nitrogen and oxygen species (including $\mathrm{NO}$, superoxide $\left(\mathrm{O}_{2}^{--}\right)$, and $\left.\mathrm{H}_{2} \mathrm{O}_{2}\right)$ contribute to limit the growth of the bacilli in vivo $(43,47,73-78)$.

The ability of $M$. leprae to persist in vivo in the presence of reactive nitrogen and oxygen species implies the presence in this elusive mycobacterium of (pseudo-)enzymatic detoxification systems, including truncated hemoglobin $\mathrm{O}(\mathrm{trHbO})(43,77-$ 84). M. leprae trHbO has been reported to facilitate $\mathrm{NO}$ and peroxynitrite scavenging using $\mathrm{O}_{2}, \mathrm{NO}$, and $\mathrm{H}_{2} \mathrm{O}_{2}$ as co-factors (43, 47, 78, 82-84) (see Tables 1, 2, 4, 5, and 6). Interestingly, kinetics of $\mathrm{NO}$ detoxification by the heme-Fe(IV) $=\mathrm{O}$ derivative 
Table 7

Peroxynitrite scavenging by heme-Fe(III)

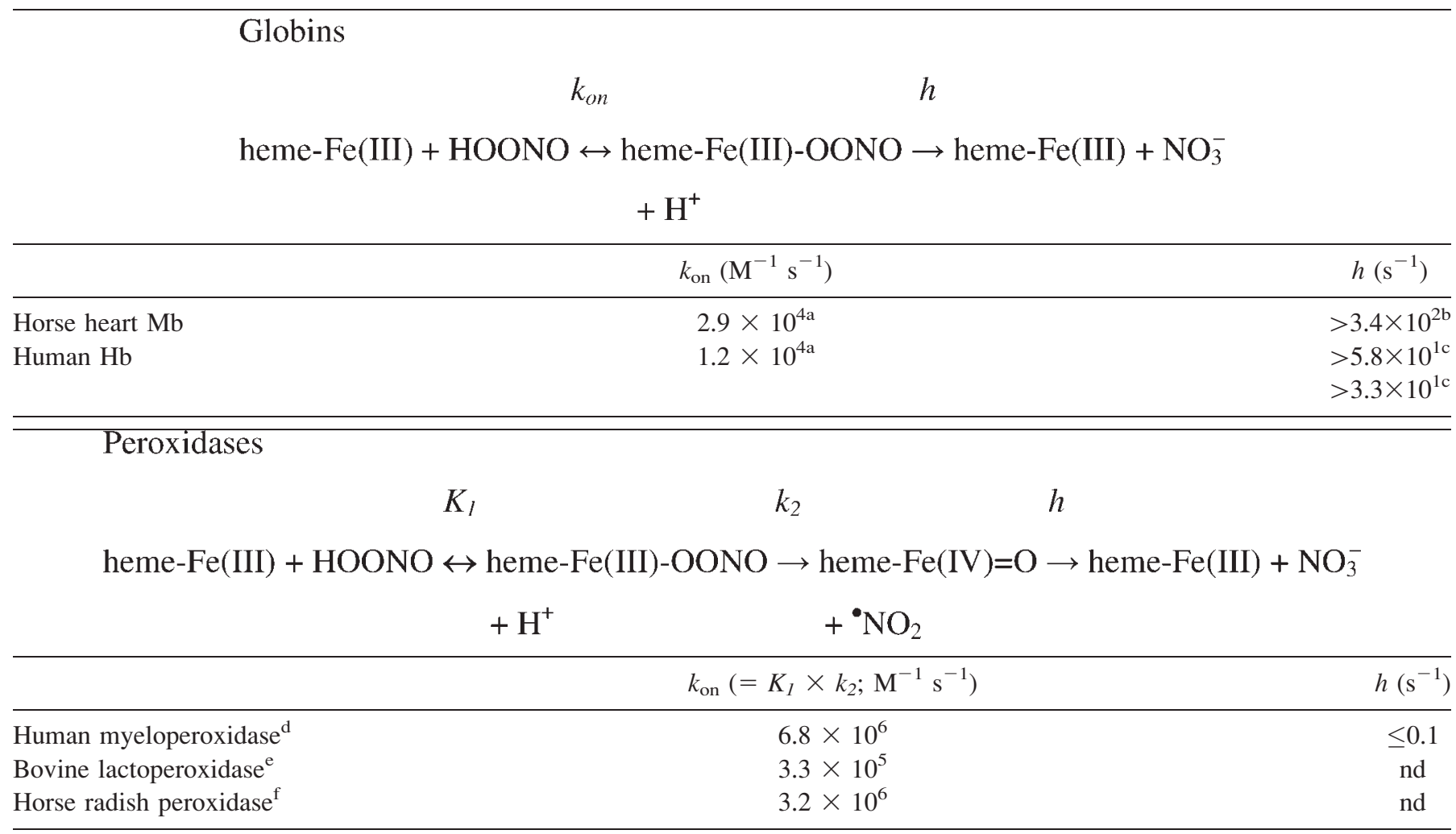

${ }^{\mathrm{a}} \mathrm{pH}=7.0$ and $20.0^{\circ} \mathrm{C}$. From (98)

${ }^{\mathrm{b}} \mathrm{pH}=7.0$ and $20.0^{\circ} \mathrm{C}$. From (90).

${ }^{\mathrm{c}}$ The two values represent the decay rates for $\mathrm{Fe}(\mathrm{III}) \mathrm{OONO} \alpha$ - and $\beta$-Hb subunits. $\mathrm{pH}=7.5$ and $20.0^{\circ} \mathrm{C}$. From $(27)$.

${ }^{\mathrm{d}} \mathrm{pH}=7.0$ and $25^{\circ} \mathrm{C}$. From $(61)$.

${ }_{\mathrm{e}}^{\mathrm{e} H}=7.4$ and $12^{\circ} \mathrm{C}$. From $(60)$.

${ }_{\mathrm{f}}^{\mathrm{f} H}=6.8$ and $25^{\circ} \mathrm{C}$. From $(60)$.

nd, not determined.

of $M$. leprae, induced by $\mathrm{H}_{2} \mathrm{O}_{2}$, is faster than any other mycobacterial reactions involved in scavenging of reactive nitrogen and oxygen species (47) (see Tables 1, 2, 4, 5, and 6). This appears to be in agreement with the absence in $M$. leprae of a specific reductase(s) converting heme-Fe(III) (obtained from the reaction of heme-Fe(II)- $\mathrm{O}_{2}$ and heme-Fe(II)-NO with $\mathrm{NO}$ and peroxynitrite) to heme-Fe(II), this enzymatic process being pivotal to start a new catalytic cycle $(43,47,77,78,82-84)$.

Paradoxically, $\mathrm{NO}$, peroxynitrite, and $\mathrm{NO}_{2}^{-}$can serve as antioxidants of the highly oxidizing heme- $\mathrm{Fe}(\mathrm{IV})=\mathrm{O}$ derivative of globins, which could be responsible for the oxidative damage of biological membranes (85) and inactivation of heme-based enzymes (e.g., cytochrome $c$ peroxidase) (86).

As a whole, peroxidases appear to be able to detoxify from oxidative compounds (such as peroxynitrite) through the oxidation of the resting heme-Fe(III) state to heme-Fe(IV) $=\mathrm{O}$ under normal oxidizing conditions. Whenever the environment becomes highly oxidative massive oxidation of globins to
heme-Fe $(\mathrm{IV})=\mathrm{O}$ takes place; this facilitates $\mathrm{NO}$, peroxynitrite, and $\mathrm{NO}_{2}^{-}$detoxification, boosting the detoxification mechanism, because $\mathrm{NO}$, peroxynitrite, and $\mathrm{NO}_{2}^{-}$can serve as antioxidants of the highly oxidizing heme-Fe(IV) $=\mathrm{O}$ species. Therefore, under these highly oxidative conditions globins appear to facilitate $\mathrm{NO}$, peroxynitrite, $\mathrm{NO}_{2}^{-}$, and $\mathrm{H}_{2} \mathrm{O}_{2}$ scavenging without needing a reductase partner(s), which in such condition is potentially devoid of reducing co-factors (e.g., NADH and $\left.\mathrm{FADH}_{2}\right)$. Although the in vivo role of heme-Fe(IV) $=\mathrm{O}$ globins in scavenging reactive nitrogen species is still uncertain, NO, peroxynitrite, and $\mathrm{NO}_{2}^{-}$could be the 'true' substrates of globins when acting as peroxidases, $\mathrm{H}_{2} \mathrm{O}_{2}$ being the co-substrate.

\section{ACKNOWLEDGEMENTS}

This work was partially supported by grants from the Ministry for Education, University, and Research of Italy (Department of Biology, University Roma Tre, Roma, Italy, 'CLAR 2008' to 


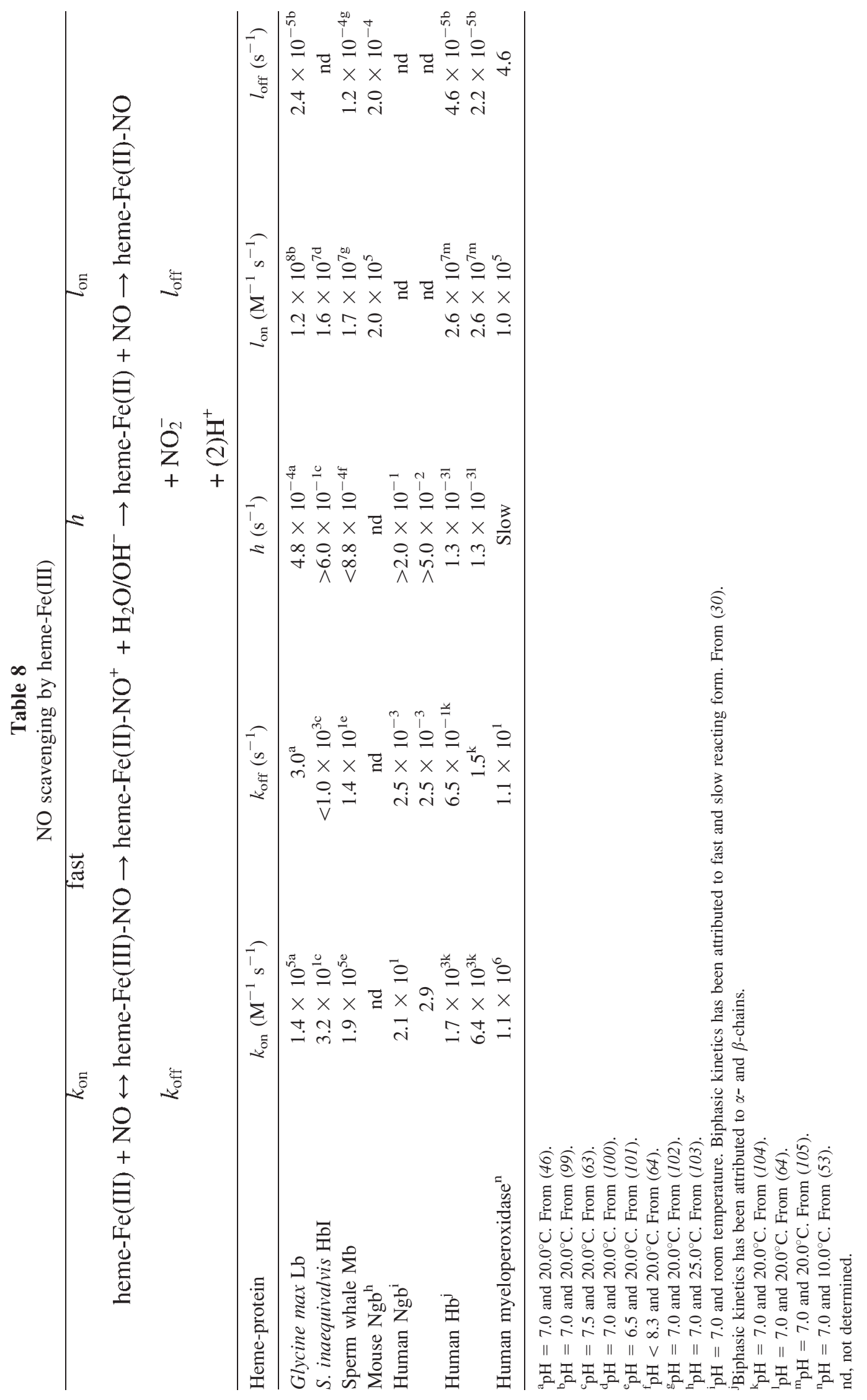




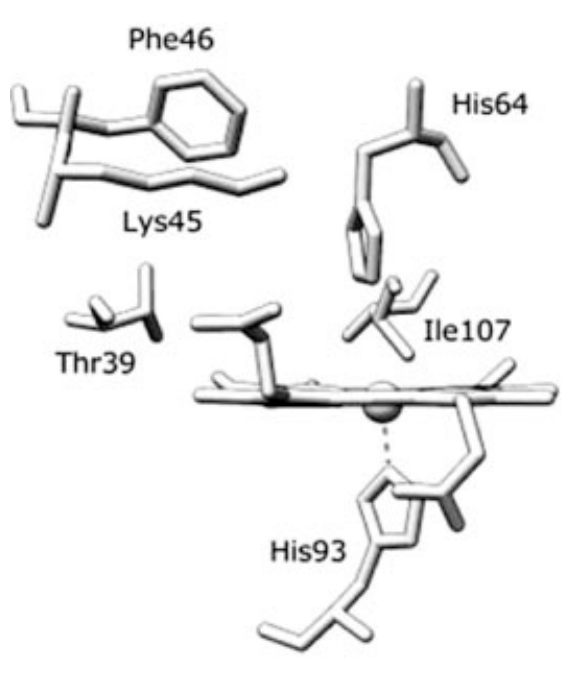

Horse heart myoglobin

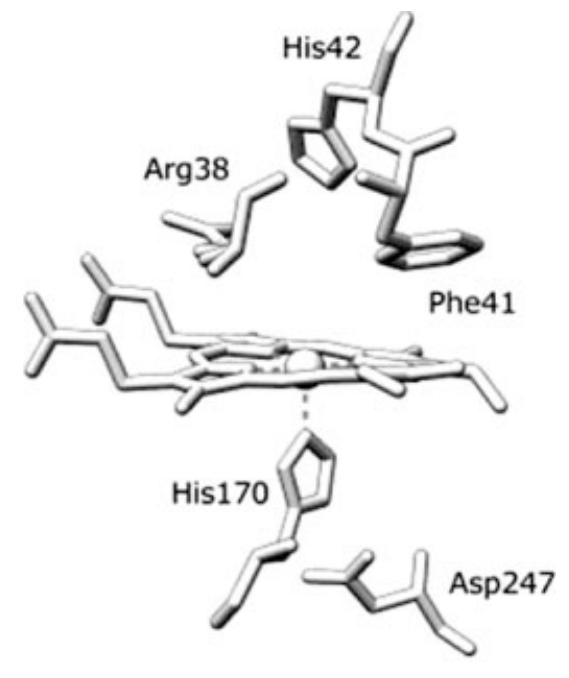

Horseradish peroxidase

Figure 1. Key residues of heme surroundings of horse heart Mb (PDB code: 2v1k) and horseradish peroxidase (PDB code: 1h58).

P.A.) and from the Ministry of Health of Italy (National Institute for Infectious Diseases I.R.C.C.S. 'Lazzaro Spallanzani', Roma, Italy, 'Ricerca corrente 2007 ' to P.A.).

\section{REFERENCES}

1. Vinogradov, S. N., Hoogewijs, D., Bailly, X., Arredondo-Peter, R., Gough, J., Dewilde, S., Moens, L., and Vanfleteren, J. R. (2006) A phylogenomic profile of globins. BMC Evol. Biol. 6, 31.

2. Vuletich, D. A. and Lecomte, J. T. (2006) A phylogenetic and structural analysis of truncated hemoglobins. J. Mol. Evol. 62, 196-210.

3. Poole, R. K. and Hughes, M. N. (2000) New functions for the ancient globin family: bacterial responses to nitric oxide and nitrosative stress. Mol. Microbiol. 36, 775-783.

4. Brunori, M. (2001) Nitric oxide moves myoglobin centre stage. Trends Biochem. Sci. 26, 209-210.

5. Weber, R. E. and Vinogradov, S. N. (2001) Nonvertebrate hemoglobins: functions and molecular adaptations. Physiol. Rev. 81, 569-628.

6. Gödecke, A., Molojavyi, A., Heger, J., Flögel, U., Ding, Z., Jacoby, C., and Schrader, J. (2003) Myoglobin protects the heart from inducible nitric-oxide synthase (iNOS)-mediated nitrosative stress. J. Biol. Chem. 278, 21761-21766.

7. Shikama, K. and Matsuoka, A. (2004) Structure-function relationships in unusual nonvertebrate globins. Crit. Rev. Biochem. Mol. Biol. 39, 217-259.

8. Freitas, T. A., Saito, J. A., Hou, S., and Alam, M. (2005) Globincoupled sensors, protoglobins, and the last universal common ancestor. J. Inorg. Biochem. 99, 23-33.

9. Gilles-Gonzalez, M. A. and Gonzalez, G. (2005) Heme-based sensors: defining characteristics, recent developments, and regulatory hypotheses. J. Inorg. Biochem. 99, 1-22.

10. Ascenzi, P., Bellelli, A., Coletta, M., Colosimo, A., Falcioni, G., Giacometti, G. M., Ippoliti, R., Zolla, L., and Giardina, B. (2007) Multiple strategies for $\mathrm{O}_{2}$ transport: from simplicity to complexity. IUBMB Life 59, 600-616.
11. Nardini, M., Pesce, A., Milani, M., and Bolognesi, M. (2007) Protein fold and structure in the truncated (2/2) globin family. Gene 398, 211.

12. Wittenberg, J. B. (2007) On optima: the case of myoglobin-facilitated oxygen diffusion. Gene 398, 156-161.

13. Bonamore, A. and Boffi, A. (2008) Flavohemoglobin: structure and reactivity. IUBMB Life 60, 19-28.

14. Vinogradov, S. N. and Moens, L. (2008) Diversity of globin function: enzymatic, transport, storage, and sensing. J Biol Chem. 283, 87738777.

15. Wilson, M. T. and Reeder, B. J. (2008) Oxygen-binding haem proteins. Exp Physiol. 93, 128-132.

16. Keilin, D. and Hartree, E. F. (1951) Purification of horse-radish peroxidase and comparison of its properties with those of catalase and methaemoglobin. Biochem. J. 49, 88-104.

17. Willick, G. E., Schonbaum, G. R., and Kay, C. M. (1969) Circular dichroism and absorption spectra of horse radish peroxidase and sperm whale myoglobin in the Soret region. Biochemistry. 8, 3729-3734.

18. Kobert, R. (1900) Beitrage zur Kenntniss der Methamoglobine. Pflügers Arch. Gesamte Physiol. Menschen Tiere. 82, 603-630.

19. Wu, H. (1923) Studies on hemoglobin: III. An ultra-micro-method for the determination of hemoglobin as a peroxidase. J. Biochem. (Tokyo) 2, 189-194.

20. Polonovski, M. and Jayle, M. F. (1938) Existence dans le plasma humain d'une substance activant l'action peroxydasique de l'hemoglobine. C. R. Hebd. Seances Mem. Soc. Biol. Ses. Fil. 129, 457-460.

21. George, P. and Irvine, D. H. (1952) The reaction between metmyoglobin and hydrogen peroxide. Biochem. J. 52, 511-517.

22. Keilin, D. and Hartree, E. F. (1955) Catalase, peroxidase and metmyoglobin as catalysts of coupled peroxidatic reactions. Biochem. J. 60, 310-325.

23. Yonetani, T. and Schleyer, H. (1967) Studies on cytochrome $c$ peroxidase. IX. The reaction of ferrimyoglobin with hydroperoxides and a comparison of peroxidase-induced compounds of ferrimyoglobin and cytochrome $c$ peroxidase. J. Biol. Chem. 242, 1974-1979.

24. Everse, J., Everse, K. E., and Grisham, M. B., Eds (1991) Peroxidases in Chemistry and Biology. Volumes I and II, CRC, Boca Raton. 
25. Redaelli, C., Monzani, E., Santagostini, L., Casella, L., Sanangelantoni, A. M., Pierattelli, R., and Banci, L. (2002) Characterization and peroxidase activity of a myoglobin mutant containing a distal arginine. Chem.Bio.Chem. 3, 226-233.

26. Abu-Soud, H. M. and Hazen, S. L. (2000) Nitric oxide is a physiological substrate for mammalian peroxidases. J. Biol. Chem. 275, 3752437532.

27. Herold, S. (1999) Kinetic and spectroscopic characterization of an intermediate peroxynitrite complex in the nitrogen monoxide induced oxidation of oxyhemoglobin. FEBS Lett. 443, 81-84.

28. Herold, S. and Fago, A. (2005) Reactions of peroxynitrite with globin proteins and their possible physiological role. Comp. Biochem. Physiol. A Mol. Integr. Physiol. 142, 124-129.

29. Fasano, M., Antonini, G., and Ascenzi, P. (2006) $\mathrm{O}_{2}$-mediated oxidation of hemopexin-heme(II)-NO. Biochem. Biophys. Res. Commun. 345, 704-712.

30. Herold, S., Fago, A., Weber, R. E., Dewilde, S., and Moens, L. (2004) Reactivity studies of the $\mathrm{Fe}(\mathrm{III})$ and $\mathrm{Fe}(\mathrm{II}) \mathrm{NO}$ forms of human neuroglobin reveal a potential role against oxidative stress. J. Biol. Chem. 279, 22841-22847.

31. Nicolis, S., Monzani, E., Ciaccio, C., Ascenzi, P., Moens, L., and Casella, L. (2007) Reactivity and endogenous modification by nitrite and hydrogen peroxide: does human neuroglobin act only as a scavenger? Biochem. J. 407, 89-99.

32. Momenteau, M. and Reed, C. (1994) Synthetic heme dioxygen complexes. Chem. Rev. 94, 659-698.

33. Exner, M. and Herold, S. (2000) Kinetic and mechanistic studies of the peroxynitrite-mediated oxidation of oxymyoglobin and oxyhemoglobin. Chem. Res. Toxicol. 13, 287-293.

34. Ascenzi, P., Ciaccio, C., and Coletta, M. (2007) Peroxynitrite-mediated oxidation of ferrous carbonylated myoglobin is limited by carbon monoxide dissociation. Biochem. Biophys. Res. Commun. 363, 931936.

35. Gow, A. J., Luchsinger, B. P., Pawloski, J. R., Singel, D. J., and Stamler, J. S. (1999) The oxyhemoglobin reaction of nitric oxide. Proc. Natl. Acad. Sci. USA 96, 9027-9032.

36. Gardner, A. M., Martin, L. A., Gardner, P. R., Dou, Y., and Olson, J. S. (2000) Steady-state and transient kinetics of Escherichia coli nitricoxide dioxygenase (flavohemoglobin) The B10 tyrosine hydroxyl is essential for dioxygen binding and catalysis. J. Biol. Chem. 275 , 12581-12589.

37. Flögel, U., Merx, M. W., Gödecke, A., Decking, U. K., and Schrader, J. (2001) Myoglobin: a scavenger of bioactive NO. Proc. Natl. Acad. Sci. USA 98, 735-740. Erratum in: Proc. Natl. Acad. Sci. USA 98, 4276.

38. Frauenfelder, H., McMahon, B. H., and Fenimore, P. W. (2003) Myoglobin: the hydrogen atom of biology and a paradigm of complexity. Proc. Natl. Acad. Sci. USA 100, 8615-8617.

39. Frey, A. D. and Kallio, P. T. (2003) Bacterial hemoglobins and flavohemoglobins: versatile proteins and their impact on microbiology and biotechnology. FEMS Microbiol. Rev. 27, 525-545.

40. Wu, G., Wainwright, L. M., and Poole, R. K. (2003) Microbial globins. Adv. Microb. Physiol. 47, 255-310.

41. Brunori, M., Bourgeois, D., and Vallone, B. (2004) The structural dynamics of myoglobin. J. Struct. Biol. 147, 223-234.

42. Frey, A. D. and Kallio, P. T. (2005) Nitric oxide detoxification - a new era for bacterial globins in biotechnology? Trends Biotechnol. 23, 69-73.

43. Ascenzi, P. and Visca, P. (2008) Scavenging of reactive nitrogen species by mycobacterial truncated hemoglobins. Methods Enzymol. 436, 317-337.

44. Herold, S. and Rehmann, F. J. (2001) Kinetic and mechanistic studies of the reactions of nitrogen monoxide and nitrite with ferryl myoglobin. J. Biol. Inorg. Chem. 6, 543-555.
45. Herold, S. and Rehmann, F. J. (2003) Kinetics of the reactions of nitrogen monoxide and nitrite with ferryl hemoglobin. Free Radic. Biol. Med. 34, 531-545.

46. Herold, S. and Puppo, A. (2005) Kinetics and mechanistic studies of the reactions of metleghemoglobin, ferrylleghemoglobin, and nitrosylleghemoglobin with reactive nitrogen species. J. Biol. Inorg. Chem. 10, 946-957.

47. Ascenzi, P., De Marinis, E., Coletta, M., and Visca, P. (2008) $\mathrm{H}_{2} \mathrm{O}_{2}$ and ${ }^{\bullet} \mathrm{NO}$ scavenging by Mycobacterium leprae truncated hemoglobin O. Biochem. Biophys. Res. Commun. 373, 197-201.

48. Nicolis, S., Monzani, E., Roncone, R., Gianelli, L., and Casella, L. (2004) Metmyoglobin-catalyzed exogenous and endogenous tyrosine nitration by nitrite and hydrogen peroxide. Chem. Eur. J. 10, 22812290.

49. Radi, R. (2004) Nitric oxide, oxidants, and protein tyrosine nitration. Proc. Natl. Acad. Sci. USA. 101, 4003-4008.

50. Goldstein, S. and Merényi, G. (2008) The chemistry of peroxynitrite: implications for biological activity. Methods Enzymol. 436, 49-61.

51. Monzani, E., Nicolis, S., Roncone, R., Barbieri, M., Granata, A., and Casella, L. (2008) Protein self-modification by heme-generated reactive species. IUBMB Life. 60, 41-56.

52. Glover, R. E., Koshkin, V., Dunford, H. B., and Mason, R. P. (1999) The reaction rates of NO with horseradish peroxidase compounds I and II. Nitric Oxide. 3, 439-444.

53. Abu-Soud, H. M. and Hazen, S. L. (2000) Nitric oxide modulates the catalytic activity of myeloperoxidase. J. Biol. Chem. 275, 54255430 .

54. Abu-Soud, H. M., Khassawneh, M. Y., Sohn, J. T., Murray, P., Haxhiu, M. A., and Hazen, S. L. (2001) Peroxidases inhibit nitric oxide (NO) dependent bronchodilation: development of a model describing NO-peroxidase interactions. Biochemistry. 40, 11866-11875.

55. Brunelli, L., Yermilov, V., and Beckman, J. S. (2001) Modulation of catalase peroxidatic and catalytic activity by nitric oxide. Free Radic. Biol. Med. 30, 709-714.

56. Burner, U., Furtmüller, P. G., Kettle, A. J., Koppenol, W. H., and Obinger, C. (2000) Mechanism of reaction of myeloperoxidase with nitrite. J. Biol. Chem. 275, 20597-20601.

57. Brück, T. B., Fielding, R. J., Symons, M. C. R., and Harvey, P. J. (2001) Mechanism of nitrite-stimulated catalysis by lactoperoxidase. Eur. J. Biochem. 268, 3214-3222.

58. Monzani, E., Roncone, R., Galliano, M., Koppenol, W. H., and Casella, L. (2004) Mechanistic insight into the peroxidase catalyzed nitration of tyrosine derivatives by nitrite and hydrogen peroxide. Eur. J. Biochem. 271, 895-906.

59. van Dalen, C. J., Winterbourn, C. C., Kettle, A. J. (2006) Mechanism of nitrite oxidation by eosinophil peroxidase: implications for oxidant production and nitration by eosinophils. Biochem. J. 394, 707-713.

60. Floris, R., Piersma, S. R., Yang, G., Jones, P., and Wever, R. (1993) Interaction of myeloperoxidase with peroxynitrite. A comparison with lactoperoxidase, horseradish peroxidase and catalase. Eur. J. Biochem. 215, 767-775.

61. Furtmüller, P. G., Jantschko, W., Zederbauer, M., Schwanninger, M., Jakopitsch, C., Herold, S., Koppenol, W. H., and Obinger, C. (2005) Peroxynitrite efficiently mediates the interconversion of redox intermediates of myeloperoxidase. Biochem. Biophys. Res. Comm. 337, 944-954.

62. Herold, S., Kalinga, S., Matsui, T., and Watanabe, Y. (2004) Mechanistic studies of the isomerization of peroxynitrite to nitrate catalyzed by distal histidine metmyoglobin mutants. J. Am. Chem. Soc. 126, 6945-6955.

63. Boffi, A., Sarti, P., Amiconi, G., and Chiancone, E. (2002) The interplay between heme iron and protein sulfhydryls in the reaction of dimeric Scapharca inaequivalvis hemoglobin with nitric oxide. Biophys. Chem. 98, 209-216. 
64. Hoshino, M., Maeda, M., Konishi, R., Seki, H., and Ford, P. C. (1996) Studies on the reaction mechanism for reductive nitrosylation of ferrihemoproteins in buffer solutions. J. Am. Chem. Soc. 118, 57025707.

65. Ascenzi, P., Bocedi, A., Visca, P., Minetti, M., and Clementi, E. (2006) Does $\mathrm{CO}_{2}$ modulate peroxynitrite specificity? IUBMB Life 58, 611-613.

66. Dunford, H. B. and Stillman, J. S. (1976) On the function and mechanism of action of peroxidases. Coord. Chem. Rev. 19, 187251.

67. Welinder, K. G., Bjørnholm, B., and Dunford, H. B. (1995) Functions of electrosctatic potentials and conserved distal and proximal His-Asp H-bonding network in haem peroxidases. Biochem. Soc. Trans. 23, 257-262.

68. Wan, L., Twitchett, M. B., Eltis, L. D., Mauk, G., and Smith, M. (1998) In vitro evolution of horse heart myoglobin to increase peroxidase activity. Proc. Natl. Acad. Sci. USA 95, 12825-12831.

69. Roncone, R., Monzani, E., Murtas, M., Battaini, G., Pennati, A., Sanangelantoni, A. M., Zuccotti, S., Bolognesi, M., and Casella, L. (2004) Engineering peroxidase activity in myoglobin: the haem cavity structure and peroxide activation in the T67R/S92D mutant and its derivative reconstituted with protohemin-L-histidine. Biochem. J. 377, 717724.

70. Choudhury, K., Sundaramoorthy, M., Hickman, A., Yonetani, T., Woehl, E., Dunn, M. F., and Poulos, T. L. (1994) Role of the proximal ligand in peroxidase catalysis. Crystallographic, kinetic, and spectral studies of cytochrome $c$ peroxidase proximal ligand mutants. J. Biol. Chem. 269, 20239-20249.

71. Rodriguez-Lopez, J. N., Smith, A. T., and Thorneley, R. N. F. (1996) Role of arginine 38 in horse radish peroxidase. A critical residue for substrate binding and catalysis. J. Biol. Chem. 271, 40234030 .

72. Tanaka, M., Ishimori, K., Mukai, M., Kitagawa, T., and Morishima, I. (1997) Catalytic activities and structural properties of horseradish peroxidase distal His $42 \rightarrow$ Glu or Gln mutant. Biochemistry. 36, 98899898.

73. MacMicking, J., Xie, Q. W., and Nathan, C. (1997) Nitric oxide and macrophage function. Annu. Rev. Immunol. 15, 323-350.

74. Ratledge, C. and Dale, J., Eds (1999) Mycobacteria, Molecular Biology and Virulence. Blackwell Science, Oxford.

75. Nathan, C. and Shiloh, M. U. (2000) Reactive oxygen and nitrogen intermediates in the relationship between mammalian hosts and microbial pathogens. Proc. Natl. Acad. Sci. USA 97, 8841-8848.

76. Cooper, A. M., Adams, L. B., Dalton, D. K., Appelberg, R., and Ehlers, S. (2002) IFN- $\gamma$ and NO in mycobacterial disease: new jobs for old hands. Trends Microbiol. 10, 221-226.

77. Visca, P., Fabozzi, G., Milani, M., Bolognesi, M., and Ascenzi, P. (2002) Nitric oxide and Mycobacterium leprae pathogenicity. IUBMB Life. 54, 95-99.

78. Ascenzi, P., Bolognesi, M., Milani, M., Guertin, M., and Visca, P. (2007) Mycobacterial truncated hemoglobins: from genes to functions. Gene. 398, 42-51.

79. Wittenberg, J. B., Bolognesi, M., Wittenberg, B. A., and Guertin, M. (2002) Truncated hemoglobins: a new family of hemoglobins widely distributed in bacteria, unicellular eukaryotes, and plants. J. Biol. Chem. 277, 871-874.

80. Milani, M., Pesce, A., Ouellet, H., Guertin, M., and Bolognesi, M. (2003) Truncated hemoglobins and nitric oxide action. IUBMB Life. 55, 623-627.

81. Milani, M., Pesce, A., Nardini, M., Ouellet, H., Ouellet, Y., Dewilde, S., Bocedi, A., Ascenzi, P., Guertin, M., Moens, L., Friedman, J. M., Wittenberg, J. B., and Bolognesi, M. (2005) Structural bases for heme binding and diatomic ligand recognition in truncated hemoglobins. J. Inorg. Biochem. 99, 97-109.
82. Ascenzi, P., Bocedi, A., Bolognesi, M., Fabozzi, G., Milani, M., and Visca, P. (2006) Nitric oxide scavenging by Mycobacterium leprae GlbO involves the formation of the ferric heme-bound peroxynitrite intermediate. Biochem. Biophys. Res. Commun. 339, 448-454.

83. Ascenzi, P., Milani, M., and Visca, P. (2006) Peroxynitrite scavenging by ferrous truncated hemoglobin GlbO from Mycobacterium leprae. Biochem. Biophys. Res. Commun. 351, 528-533.

84. Fabozzi, G., Ascenzi, P., Di Renzi, S., and Visca, P. (2006) Truncated hemoglobin GlbO from Mycobacterium leprae alleviates nitric oxide toxicity. Microb. Pathog. 40, 211-220.

85. Rubbo, H., Radi, R., Anselmi, D., Kirk, M., Barnes, S., Butler, J., Eiserich, J. P., and Freeman, B. A. (2000) Nitric oxide reaction with lipid peroxyl radicals spares $\alpha$-tocopherol during lipid peroxidation. Greater oxidant protection from the pair nitric oxide/ $\alpha$-tocopherol than $\alpha$-tocopherol/ascorbate. J. Biol. Chem. 275, 10812-10818.

86. Brunori, M., Forte, E., Arese, M., Mastronicola, D., Giuffrè, A., and Sarti, P. (2006) Nitric oxide and the respiratory enzyme. Biochim. Biophys. Acta 1757, 1144-1154.

87. Ouellet, H., Ouellet, Y., Richard, C., Labarre, M., Wittenberg, B., Wittenberg, J., and Guertin, M. (2002) Truncated hemoglobin HbN protects Mycobacterium bovis from nitric oxide. Proc. Natl. Acad. Sci. USA 99, 5902-5907.

88. Ouellet, H., Juszczak, L., Dantsker, D., Samuni, U., Ouellet, Y. H., Savard, P. Y., Wittenberg, J. B., Wittenberg, B. A., Friedman, J. M., and Guertin, M. (2003) Reactions of Mycobacterium tuberculosis truncated hemoglobin $\mathrm{O}$ with ligands reveal a novel ligand-inclusive hydrogen bond network. Biochemistry 42, 5764-5774.

89. Herold, S. and Puppo, A. (2005) Oxyleghemoglobin scavenges nitrogen monoxide and peroxynitrite: a possible role in functioning nodules? Biol. Inorg. Chem. 10, 935-945.

90. Herold, S., Exner, M., and Nauser, T. (2001) Kinetic and mechanistic studies of the $\mathrm{NO}^{\bullet}$-mediated oxidation of oxymyoglobin and oxyhemoglobin. Biochemistry 40, 3385-3395.

91. Brunori, M., Giuffrè, A., Nienhaus, K., Nienhaus, G. U., Scandurra, F. M., and Vallone, B. (2005) Neuroglobin, nitric oxide, and oxygen: functional pathways and conformational changes. Proc. Natl. Acad. Sci. USA 102, 8483-8488.

92. Herold, S., Exner, M., and Boccini, F. (2003) The mechanism of the peroxynitrite-mediated oxidation of myoglobin in the absence and presence of carbon dioxide. Chem. Res. Toxicol. 16, 390402.

93. Boccini, F. and Herold, S. (2004) Mechanistic studies of the oxidation of oxyhemoglobin by peroxynitrite. Biochemistry. 43, 16393 16404.

94. Møller, J. K. and Skibsted, L. H. (2004) Mechanism of nitrosylmyoglobin autoxidation: temperature and oxygen pressure effects on the two consecutive reactions. Chem. Eur. J. 10, 2291-2300.

95. Herold, S. and Röck, G. (2005) Mechanistic studies of the oxygenmediated oxidation of nitrosylhemoglobin. Biochemistry. 44, 62236231.

96. Herold, S. and Boccini, F. (2006) $\mathrm{NO}^{\bullet}$ release from $\mathrm{MbFe}(\mathrm{II}) \mathrm{NO}$ and $\mathrm{HbFe}(\mathrm{II}) \mathrm{NO}$ after oxidation by peroxynitrite. Inorg. Chem. 45, 69336943.

97. Herold, S. (2004) The outer-sphere oxidation of nitrosyliron(II)hemoglobin by peroxynitrite leads to the release of nitrogen monoxide. Inorg. Chem. 43, 3783-3785.

98. Herold, S. and Shivashankar, K. (2003) Metmyoglobin and methemoglobin catalyze the isomerization of peroxynitrite to nitrate. Biochemistry. 42, 14036-14046.

99. Rohlfs, R. J., Olson, J. S., and Gibson, Q. H. (1988) A comparison of the geminate recombination kinetics of several monomeric heme proteins. J. Biol. Chem. 263, 1803-1813.

100. Chiancone, E. and Gibson, Q. H. (1989) Ligand binding to the dimeric hemoglobin from Scapharca inaequivalvis, a hemoglobin with 
a novel mechanism for cooperativity. J. Biol. Chem. 264, 2106221065.

101. Hoshino, M., Oawa, K., Seki, H., and Ford, P. C. (1993) Photochemistry of nitric oxide adducts of water-soluble iron (III)porphyrin and ferrihemoproteins studied by nanosecond laser photolysis. J. Am. Chem. Soc. 115, 9568-9575.

102. Moore, E. G. and Gibson, Q. H. (1976) Cooperativity in the dissociation of nitric oxide from hemoglobin. J. Biol. Chem. 251, 27882794.
103. Van Doorslaer, S., Dewilde, S., Kiger, L., Nistor, S. V., Goovaerts, E., Marden, M. C., and Moens, L. (2003) Nitric oxide binding properties of neuroglobin: a characterization by EPR and flash photolysis. J. Biol. Chem. 278, 4919-4925.

104. Sharma, V. S., Traylor, T. G., Gardiner, R., and Mizukami, H. (1987) Reaction of nitric oxide with heme proteins and model compounds of hemoglobin. Biochemistry 26, 3837-3843.

105. Cassoly, R. and Gibson, Q. (1975) Conformation, co-operativity and ligand binding in human hemoglobin. J. Mol. Biol. 91, 301-313. 